\title{
A Model of Economic Growth for an Open Emerging Country: Empirical Evidence for Brazil
}

Philip Arestis, University of Cambridge, UK, and Carolina Troncoso Baltar, ${ }^{1}$ University of

Campinas, Institute of Economics, Brazil

\section{Abstract}

Brazil liberalised its trade and finance in the 1990s as a strategy for higher economic growth. However, the country's GDP growth has been unstable and low compared to its own performance during the industrialization period. This paper builds a model of economic growth that accounts for the main components of effective demand as well as important specificities of emerging economies to explain the economic dynamics after the liberalising reforms. The model is estimated for the case of Brazil from 1990 to 2014 and the results suggest that this economy became highly dependent on the world economic growth and the evolution of the real exchange rate. The main finding is that Brazil experiences higher economic growth only in favourable world scenarios but the evolution of the real exchange rate in this scenario may stimulate investments that only reinforce the existing productive structure, affecting negatively the long-run economic growth.

Key Words: economic growth, effective demand, real exchange rate

JEL Classification: O40, E12, F43

\section{Introduction}

Brazil liberalised its trade and finance in the 1990s as a strategy for higher economic growth, replacing the Import Substitution Industrialisation (ISI) strategy. The ISI period (1950-1980) generated high economic growth rates and the country built a diversified manufacturing industry (Belluzzo and Almeida, 2002; Carneiro, 2002). However, the economic stagnation, high inflation and the collapse of the public finance during the debt crisis in the 1980s reduced the Brazilian State capacity to intervene in the economy and the necessary investments to keep the industrial structure updated were not undertaken. The Brazilian industrial structure was delayed compared to industrialised countries; at the same time the world industrial production went through important changes, such as in its business organization and technological advancements (Belluzzo and Almeida, 2002).

\footnotetext{
${ }^{1}$ Carolina Troncoso Baltar is very greatful to “Coordenação de Aperfeiçoamento de Pessoal de Nível Superior” (CAPES) for financial support.
} 
The difficulties to resolve the balance of payments disequilibrium, to slow down inflation and to resume GDP growth influenced the Brazilian government to liberalise trade and finance and to privatize state industries and public utility services. According to Rodrik (2004), the result of the liberalising reforms in some Latin American countries, including Brazil, was slower economic growth, compared to other parts of the world and to their own performance in the 1960s and 1970s.

The central purpose of this paper is to understand the Brazilian economic dynamics after trade and financial liberalisation, specifically the reasons underlying its unstable economic growth and its poorer performance compared to its industrialization period. To achieve this aim, we develop a model of economic growth that accounts for the main components of effective demand in the determination of economic activity as well as important features of emerging countries.

Rodrik (2004) uses a standard model of economic growth to verify the constraints to some countries economic performances. The model considers the return from accumulating physical capital, human capital entrepreneurship, technology and so forth, and examines how these returns are appropriable by private entrepreneurs and the cost of financing accumulation. The conclusion for the case of Brazil is that there is low investment to GDP ratios and the reason is that interest rates are extremely high (Rodrik, 2004). Thus, the Brazilian economic growth became unstable and relatively low because the trade and financial liberalisation made the country's interest rates increase and investment rate reduced. Considering this diagnostic, the contribution of this paper is to go further in the analysis and show that the development strategy to improve the domestic market of financial assets, attracting foreign investment, increased the dependence of the Brazilian economic performance (in terms of GDP growth and inflation) in relation to the international situation, with negative consequences for the long run economic growth.

Capital movements towards the domestic market of financial assets made it that changes in the exchange rate were not related to the country's external trade. In favourable moments, the realised 
investment did not change the productive structure of the economy in a way to increase its international competitiveness. At this moment, capital movements towards the domestic market of financial assets reduced the nominal exchange rate, stimulating imports. Domestic inflation was reduced and the economic activity improved, especially in activities that do not compete with foreign production. However, domestic inflation was still higher than international inflation, because the non-tradable inflation did not reduce as much as the tradable inflation (Baltar, 2015). Consequently, in favourable international moments for the Brazilian economy, GDP growth increased and inflation reduced, but the national currency appreciated and the necessary investment to improve the country's competitiveness did not take place. Under this scenario, consumption and investment increased, but part of the increase in the domestic demand was transferred to other countries. When the world scenario changed, the performance of the Brazilian economy in terms of GDP growth and inflation deteriorated.

The model developed in this paper shows that after the trade and financial liberalisation, the evolution of the real exchange rate was directly related to the country's net exports, but the relation with the domestic demand (consumption and investment) was inversely related and the latter predominated in the determination of the economic activity. Higher economic growth together with national currency appreciation did not contribute to stimulate investment to improve the country's competitiveness. Consequently, GDP growth oscillated around a lower growth trend.

The paper is organized in six sections, including this introduction. Section two presents some stylised facts for the Brazilian economy. Section three puts forward the theoretical framework, based on the Keynesian tradition. Section four develops the model of growth for an open emerging country. Section five estimates the model for the case of Brazil after trade and financial liberalisation. And section six summarises and concludes. 


\section{Stylised Facts for the Brazilian Economy}

Table 1 shows the Brazilian GDP, Exports, World GDP and Real Exchange Rate, all in level and in growth rates. The table reveals that Brazilian GDP growth is unstable with a short period of relatively higher growth rates between 2004 and 2008. Despite this short period, the Brazilian average GDP growth rate after the liberalising reforms was low, especially compared to the growth rates verified during the ISI period. ${ }^{2}$ Moreover, when the world scenario changes due to the Great Recession, the country is no longer able to sustain its previous GDP growth rate.

Table 1: GDP, World GDP, Exports, Imports and Real Exchange Rate (level and growth rates)

\begin{tabular}{l|ccccc|ccccc}
\hline & $\begin{array}{c}\text { Domestic } \\
\text { GDP }\end{array}$ & $\begin{array}{c}\text { World } \\
\text { GDP }\end{array}$ & Exports & Imports & $\begin{array}{c}\text { Real } \\
\text { Exchange } \\
\text { Rate }\end{array}$ & $\begin{array}{c}\text { Domestic } \\
\text { Growth }\end{array}$ & $\begin{array}{c}\text { World } \\
\text { Growth }\end{array}$ & $\begin{array}{c}\text { Exports } \\
\text { Growth }\end{array}$ & $\begin{array}{c}\text { Imports } \\
\text { Growth }\end{array}$ & $\begin{array}{c}\text { Changes in Real } \\
\text { Exchange Rate }\end{array}$ \\
\hline 1992 & 100.5 & 102.3 & 113.2 & 97.7 & 115.6 & -0.5 & 2.3 & 13.2 & -2.3 & 15.6 \\
1993 & 105.2 & 104.6 & 121.9 & 120.0 & 110.9 & 4.7 & 2.1 & 7.7 & 22.9 & -4.0 \\
1994 & 110.8 & 108.0 & 137.7 & 157.2 & 98.8 & 5.3 & 3.3 & 12.9 & 31.0 & -10.9 \\
1995 & 115.7 & 111.7 & 147.1 & 237.5 & 81.2 & 4.4 & 3.4 & 6.8 & 51.1 & -17.8 \\
1996 & 118.1 & 116.0 & 151.0 & 253.5 & 76.5 & 2.1 & 3.9 & 2.7 & 6.8 & -5.8 \\
1997 & 122.1 & 120.8 & 167.6 & 284.0 & 74.3 & 3.4 & 4.1 & 11.0 & 12.0 & -2.8 \\
1998 & 122.1 & 123.8 & 161.7 & 274.5 & 77.6 & 0.0 & 2.5 & -3.5 & -3.3 & 4.4 \\
1999 & 122.5 & 128.3 & 151.8 & 234.3 & 116.3 & 0.3 & 3.6 & -6.1 & -14.6 & 49.9 \\
2000 & 127.7 & 134.4 & 174.3 & 265.4 & 106.9 & 4.3 & 4.8 & 14.8 & 13.3 & -8.1 \\
2001 & 129.4 & 137.8 & 184.3 & 264.3 & 132.7 & 1.3 & 2.5 & 5.7 & -0.4 & 24.1 \\
2002 & 133.4 & 141.8 & 191.1 & 224.5 & 146.7 & 3.1 & 2.9 & 3.7 & -15.0 & 10.5 \\
2003 & 135.0 & 147.5 & 231.5 & 229.7 & 151.9 & 1.2 & 4.0 & 21.1 & 2.3 & 3.6 \\
2004 & 142.7 & 155.4 & 305.7 & 298.6 & 149.4 & 5.7 & 5.4 & 32.1 & 30.0 & -1.6 \\
2005 & 147.1 & 163.0 & 374.8 & 349.8 & 121.8 & 3.1 & 4.9 & 22.6 & 17.1 & -18.5 \\
2006 & 153.0 & 172.0 & 435.8 & 434.2 & 108.9 & 4.0 & 5.5 & 16.3 & 24.1 & -10.6 \\
2007 & 162.2 & 181.8 & 508.1 & 573.3 & 101.0 & 6.0 & 5.7 & 16.6 & 32.0 & -7.2 \\
2008 & 170.3 & 187.4 & 626.0 & 822.2 & 97.4 & 5.0 & 3.1 & 23.2 & 43.4 & -3.6 \\
2009 & 170.0 & 187.4 & 483.8 & 607.0 & 96.4 & -0.2 & -0.01 & -22.7 & -26.2 & -1.1 \\
2010 & 183.0 & 197.5 & 638.6 & 863.3 & 84.6 & 7.6 & 5.4 & 32.0 & 42.2 & -12.2 \\
2011 & 190.0 & 205.8 & 809.7 & 1075.1 & 82.3 & 3.9 & 4.2 & 26.8 & 24.5 & -2.7 \\
2012 & 193.4 & 212.8 & 767.2 & 1060.7 & 92.3 & 1.8 & 3.4 & -5.3 & -1.3 & 12.2
\end{tabular}

2 The Brazilian average GDP growth rate between 1950 and 1980 (industrialization period) was $7.4 \%$ per year and between 1990 and 2011 (period after liberalising reforms) was on average $2.7 \%$ per year. 


\begin{tabular}{l|lllll|llll}
2013 & 198.7 & 220.1 & 765.4 & 1139.5 & 98.7 & 2.7 & 3.4 & -0.2 & 7.4 \\
2014 & 198.9 & 227.5 & 711.9 & 1989.1 & 100.1 & 0.1 & 3.4 & -7.0 & -4.4 \\
\hline
\end{tabular}

Source: Own calculations with data from the Central Bank of Brazil (2016) and IMF (2016). GDP and World GDP are at constant prices. The year-base for the Index for GDP is 1990 and for the World GDP, Exports and Imports is 1991. Exports and Imports are related only to goods in US\$ dollars. Real Exchange Rate is the real effective exchange rate index ER $* \mathrm{P}_{\mathrm{i}} / \mathrm{P}_{\mathrm{d}}$, with June/1994 = 100 , where ER is the nominal exchange rate (domestic currency unit per foreign currency unit), $\mathrm{P}_{\mathrm{i}}$ is international price and $\mathrm{P}_{\mathrm{d}}$ is domestic price.

Table 1 also shows that domestic GDP, world GDP and exports follow the same path, both in level and growth rates. The Pearson's correlation coefficient (Wooldridge, 2003) for GDP growth and exports growth in the considered period was 0.71 and for GDP growth and world growth was 0.62 , suggesting that world economic growth and exports growth have an influence on the dynamics of domestic GDP.

Imports are directly correlated with GDP and inversely correlated with the real exchange rate. Thus, higher economic growth with currency appreciation probably increases the country's imports. The opposite would occur when GDP decreases and the national currency depreciates.

The Pearson's correlation coefficient for domestic GDP growth and changes in the real exchange rate is negative (-0.59). Even if we exclude the year 1999, a big outlier, the correlation coefficient remains the same (-0.60). This coefficient is expected to be positive if the impact of the real exchange rate on GDP takes place through net exports. In this case, an increase in the real exchange rate would stimulate net exports, positively affecting the country's economic activity. Conversely, a currency appreciation would make imports relatively cheaper, therefore stimulating imports and affecting negatively exports, with negative consequences for the country's GDP. However, the correlation is negative, suggesting that the effect of changes in the real exchange rate on the country's economic activity may be more complex than what the standard theory implies for the case of Brazil after trade and financial liberalisation. In the Brazilian experience, the relation between real exchange rate and trade (exports and imports) is the one expected by the traditional theory. This is because it is 
not the trade conditions that determine the evolution of the real exchange rate in the short run. The latter is related with the domestic demand (consumption and investment) that, in turn, have an important impact on GDP growth in the short run compared with net exports.

There is an important debate on the effects of exchange rates on Brazil's economic performance. Bresser-Pereira (2009 and 2011) and Nassif et al. (2011), for example, are concerned with the impact of the currency overvaluation on the long-run economic growth. Additionally, IEDI (2012) points out that the increasing globalisation of the manufacturing production together with misalignments in the real exchange rate can cause irreversible losses in the manufacturing structure of countries with overvalued currency. Table 1 shows that higher economic activity occurred during periods of decreases in the real exchange rate and lower economic activity occurred during periods of increases in the real exchange rate. In this case, even with a simple oscillation in the real exchange rate without a clear trend, changes in the real exchange rate would probably affect negatively the economic growth trend.

The concern with the impact of a currency overvaluation on the Brazilian economic growth brought back the deindustrialisation debate. According to Palma (2005), Brazil is going through a process of deindustrialisation as a consequence of trade and financial liberalisation. Palma (op. cit.), Nassif (2006) and IEDI (2007) identify the process of deindustrialisation as lower share of manufacturing in the GDP growth or total employment as well as changes in the manufacturing production structure. In the last case, a process of deindustrialisation would be identified as a higher share of sectors intensive in natural resource vis-à-vis sectors intensive in capital, knowledge and technology.

This paper does not neglect the idea that trade and financial liberalisation changed the country's industrial production as well as the relationship between value added and employment in the manufacturing sector. But, it is important to distinguish the 1990s from the 2000s. The value added per 
worker in the manufacturing industry decreased in the 1980s, during the external debt crisis, and it increased in the 1990s, after the trade and financial liberalisation (Ferreira and Rossi, 2003). The possibility to import cheap inputs with better quality had an immediate impact, increasing the value added per worker in the manufacturing industry, and it contributed to increase consumption, especially durable goods (Lisboa et al., 2010). However, the increase in total value added in the manufacturing industry was low in the 1990s and industrial employment reduced considerably. After trade and financial liberalisation, the national currency appreciated, imports increased more than exports and GDP growth was low, despite the increase in the value added per worker in the manufacturing industry.

For some authors, such as Mesquita Moreira and Najberg (2000), trade liberalisation raised the manufacturing productivity, but it took place under an unfavourable macroeconomic scenario for the performance of GDP. According to the authors, this is because the nominal exchange rate was used to lower inflation and it was not possible to correct properly the national currency appreciation due to the international situation after the Mexican crisis in 1994/1995. The simultaneity of trade and financial liberalisations indicates that the development strategy of the 1990s aimed to attract capital inflow to decrease inflation and to develop the domestic market of financial assets. In the short run, the national currency appreciation took place at the same time GDP growth increased, but the investment to improve the country's competitiveness did not take place, despite the higher value added per worker in the manufacturing industry. Consumption of durable goods increased significantly, but GDP growth was low and the unemployment rate increased. This low GDP growth was negatively affected but the Asian and the Russian crisis in 1997 and 1998.

The international situation improved for the Brazilian economy in 2000. However, basic aspects of the development strategy implemented with the trade and financial liberalisation of the 1990s were maintained. Financial liberalisation was intensified and the better performance of exports and capital inflow to the domestic market of financial assets appreciated the national currency. However, the better 
performance of GDP in the 2000s compared with the 1990s cannot be explained only by the better performance of exports. It was also important that the changes, which took place in the State intervention that aimed to improve the economic performance, had positive effects on the well-being of the population (Araujo et al., 2015). It was important for the incomes policy to improve the situation of families with low income through increases in minimum wage and the social security benefits, the policy to support special productive activities, including imports regimes that favour external purchases of inputs; it controlled the purchase of final goods, and public banks were used to finance investment with lower interest rates. GDP growth increased in the 2000s and the unemployment rate decreased, but the necessary investment to strengthen the Brazilian competitiveness did not take place. Consequently, it was difficult to sustain the country's GDP growth when the world scenario changed after the global financial crisis.

In short, this paper contributes to the debate by explaining the difficulties Brazil has faced to boost its economic growth after trade and financial liberalisation, as revealed by Table 1 . In this sense, the paper discusses how the economy evolves after trade and financial liberalisation and how its performance became dependent on the international scenario.

\section{Theoretical Propositions}

In the Keynesian tradition, the effective demand determines the use of the production capacity. Consumption uses the production capacity while investment increases it. Therefore, investment is crucial for the continuity of production growth. Two types of investment can be distinguished: one that increases the production capacity without changing products and productivity and another that introduces new products and increases productivity (Possas, 1987). Investment that only increases the production capacity is the result of higher sales expectations, without changing the competitors' position in the market. In this case, expectations of sales of each supplier correspond to the expectations of the total sales in the market. Investments that introduce new products and increase 
productivity change the competitors' position in the market. The suppliers that improve products and processes are expected to grow, absorbing part of the market that belongs to other suppliers. This market competition with new products and production processes can increase the volume of total sales in the market. Higher sales associated with changes in products and productivity have an important role in the determination of the trajectory of production growth. ${ }^{3}$

In the case of investment that introduces technical progress, the activity sectors have different potentialities. They include novelties and increase productivity in terms of the nature of their own products and processes. Changes in products in one sector can facilitate changes in products and processes in other sectors. In an economy with high share of these sectors that creates new products and increase productivity, its growth tends to be higher than in an economy that only uses these new products and processes. Economic growth would be higher when both production and the use of these products are combined.

Similar considerations on the different sectoral innovation made Kaldor (1967) highlight the importance of the manufacturing production to economic growth. Schematically, it is possible to affirm that processing primary production of natural resources tends to present lower returns to scale; while in manufacturing production, returns tend to be higher when the production scale is greater. In services, higher production scale tends to keep constant returns (Lall, 2003). Accordingly, manufacturing growth is crucial for the economic growth process. Manufacturing growth introduces new products and increases productivity, not only in the manufacture, but also in the primary production and services (McCombie and Thirlwall, 1994).

\footnotetext{
${ }^{3}$ The Neo-Shumpeterian approach is appropriate to study industrial transformation and long run trajectories. This approach considers transformation processes that take place on the industry level, taking into account innovation, and show how the trajectory of economic growth is related to the productive structure of each economy. For a discussion of this topic, see Dosi and Soete (1988), Malerba (2002), Dopfer et al. (2004), Hanusch (1999) and Saviotti and Pyka (2004).
} 
Kaldor (1967) presents some empirical generalisations, which attempt to explain economic growth (McCombie and Thirlwall, 1994). The first proposition affirms that the faster the rate of growth of the manufacturing output, the faster will be the rate of growth of labour productivity in manufacturing due to the existence of static and dynamic economies of scale or increasing returns to scale. This proposition is known in the literature as Verdoorn's Law and it is often pointed out as a key player in models of circular and cumulative causation in the Kaldorian tradition. The second proposition affirms that there is a strong positive relationship between industrial sector growth rate and the productivity growth outside the industrial sector. Finally, the last proposition maintains that the faster the rate of growth of the manufacturing sector, the faster will be the rate of growth of GDP. In short, and in McCombie and Thirlwall's (1994) words: "Kaldor substantiates the role of manufacturing as the 'engine of growth"” (p. 166).

International relationships (both trade and finance) are crucial for the performance of an open economy. Thus, the balance of payments should be properly accounted. McCombie and Thirlwall (1994) point out three main reasons for the importance of considering carefully the balance of payments, especially its current account, and its effects on the growth performance. The first one is related to the direct effects of the behaviour of exports and imports on the domestic activity. An adverse long-run trend in the performance of net exports will have negative implications for the real output and employment. In this sense, the balance of payments has implications for the functioning of the real economy. The second reason is that no country can grow faster in the long run than that rate consistent with balance of payments equilibrium on current account, unless it can finance ever growing deficits. In the short term, growing current account deficits may be financed by capital inflow, but this is not possible to maintain in the long run. ${ }^{4}$ And finally, the third reason is that high interest rates favour the

\footnotetext{
${ }^{4}$ Several models of economic growth incorporate the balance of payments restriction along with a Kaldorian framework. For a discussion of these models, see McCombie and Thirlwall (1994), Thirlwall (1979, 2011), Dixon and Thirlwall (1979), Lopez and Cruz (2000), Thirlwall and Hussain (1982), Moreno-Brid (1998-9, 2003), Araujo and Lima (2007) and Cimoli
} 
attraction of foreign capital to domestic financial assets market, which discourages investment in productive assets. The conclusion of McCombie and Thirlwall (1994) is that dynamic exports are required to cover imports and other components of the current account of the balance of payments for a country to have higher economic growth.

The Kaldorian approach to economic growth takes into account these previous considerations. Dixon and Thirlwall (1975) formalize the Kaldor's approach as follow:

$$
\begin{aligned}
& \mathrm{y}_{\mathrm{t}}=\mathrm{c}_{1} \mathrm{X}_{\mathrm{t}} \\
& \mathrm{x}_{\mathrm{t}}=\mathrm{c}_{2}\left(\mathrm{p}_{\mathrm{i}, \mathrm{t}}+\mathrm{er}_{\mathrm{t}}-\mathrm{p}_{\mathrm{d}, \mathrm{t}}\right)+\mathrm{c}_{3} \mathrm{Z}_{\mathrm{t}} \\
& \mathrm{pd}_{\mathrm{t}}=\omega-\mathrm{pr}_{\mathrm{t}}+\tau \\
& \mathrm{pr}_{\mathrm{t}}=\mathrm{pr}_{\mathrm{a}}+\lambda \mathrm{y}_{\mathrm{t}}
\end{aligned}
$$

where $\mathrm{y}$ is the growth rate of GDP, $\mathrm{x}$ is the growth rate of exports, $\mathrm{z}$ is the growth rate of world GDP, $p_{i}$ is the international inflation, er is the growth rate of the nominal exchange rate (i.e., the price of international currency in domestic currency), $\mathrm{p}_{\mathrm{d}}$ is the domestic inflation, $\omega$ is the growth rate of nominal wages, $\mathrm{pr}$ is the growth rate of productivity, $\mathrm{pr}_{\mathrm{a}}$ is the autonomous productivity growth and $\tau$ is the growth rate of mark-up.

Setterfield (2010) simplified Dixon and Thirlwall's model assuming that er $=0, \tau=0$ and $\omega=$ $\omega_{\mathrm{w}}$, in which $\omega_{\mathrm{w}}$ is the growth rate of world wages. The author shows that under these circumstances, the system solution is the following:

$$
\mathrm{y}_{\mathrm{t}}=\Omega+\mathrm{c}_{1} \mathrm{c}_{2} \mathrm{pr}_{\mathrm{t}}
$$

where $\Omega=\mathrm{c}_{1}\left[\left(\mathrm{c}_{3}-\lambda_{\mathrm{w}} \mathrm{c}_{2}\right) \mathrm{Z}_{\mathrm{t}}-\mathrm{c}_{2} \mathrm{pr}_{\mathrm{a}}\right.$ and the subscript $\mathrm{w}$ refers to the world.

and Porcile (2010). Many other studies validated the model of growth constrained by the balance of payments for various countries, including emerging ones, such as Britto (2008), Carvalho et al. (2005), Carvalho and Lima (2009), Jayme Jr. (2003) and Pacheco-López and Thirlwall (2005). 
This means that, considering the influence of exports growth on GDP growth $\left(\mathrm{c}_{1}\right)$, the income elasticity of demand for exports $\left(c_{3}\right)$, the Verdoorn coefficient of other countries $\left(\lambda_{w}\right)$, the price elasticity of demand for exports $\left(c_{2}\right)$, the world GDP growth, and the autonomous growth rate of productivity $\left(\mathrm{pr}_{\mathrm{a}}\right)$, the Dixon and Thirlwall model determine the country's GDP growth and the increase in its productivity.

According to Setterfield (2010), the Kaldorian approach to economic growth is characterized by an economic growth led by demand, the crucial role of exports in the determination of this demand as well as that GDP growth is path dependent. A way to consider a path dependent economic growth is supposing that structural changes take place in the economy. There are different ways to incorporate structural changes in Kaldorian models of economic growth. In the case of Setterfield (2010), these changes take place through changes in the Verdoorn coefficient, i.e. changes in the effect of GDP growth on productivity $(\lambda)$. Initially, a fast economic growth development activities and technologies, promote specialization and increase productivity. There is an inter-relation between the different components of the specialized production (equipment, human resources, etc.). When these inter-related specialized components are accumulated, it may become difficult to undertake technical changes, because it should involve a vast range of components (lock-in in the technological base). Setterfield (2010) describes this possibility considering discrete increases in the Verdoorn coefficient that in turn, increase $\mathrm{y}$ and $\mathrm{q}$; and when the lock-in takes place, $\mathrm{y}$ and $\mathrm{q}$ are reduced.

The analysis of the difficulties to implement structural changes in stablished structures is an important aspect of the Kaldorian approach to economic growth. These difficulties of structural changes are specific for open emerging economies that aim to develop the domestic market of financial assets stimulating capital inflow. The model developed in the next section aims to analyse the effects of trade and financial liberalisation of emerging economies on the performance of these economies, increasing their dependence on the international situation and with consequences for the long-run trend. 


\section{Economic Growth Model for an Open Emerging Economy}

The understanding of economic growth processes for the case of emerging economies should account for some important specificities of these economies. In the case of the model developed in this paper, we consider the emerging economy's currency, its high short-term public debt ${ }^{5}$ and an inflationary policy based on high interest rates. A specificity of emerging economies' currencies is that they do not perform their money functions in an international context, making the exchange rate highly volatile, therefore affecting domestic inflation. ${ }^{6}$ We also consider an inflation policy that accounts for a macroeconomic policy of activity slowdown with high bank rate, primary surplus (tax revenues higher than non-financial expenditures from the State) and flexible exchange rate. ${ }^{7}$

The effective demand assumption implies that aggregate demand determines sales; sales determine production and production determines income and employment. Firms and/or producers take into consideration their expectations about future profit to decide the amount of production, therefore determining the level of production and employment. Changes in expectations can make entrepreneurs to alter their production, consequently influencing the level of employment (Davidson, 2001).

Aggregate demand (AD) consists of domestic consumption (C), government expenditure $(\mathrm{G})$, gross investment (I) and net exports, which is the difference between exports (X) and imports (Q), as in (6):

$$
\mathrm{AD}_{\mathrm{t}}=\mathrm{C}_{\mathrm{t}}+\mathrm{I}_{\mathrm{t}}+\mathrm{G}+\mathrm{X}_{\mathrm{t}}-\mathrm{Q}_{\mathrm{t}}=\mathrm{Y}_{\mathrm{t}}
$$

\footnotetext{
${ }^{5}$ The term 'high short-term public debt' is explained in equation 13 for the market interest rate.

6 The discussion of developing countries' currency refers to the existence of a currency hierarchy, in which emerging economies' currencies are in the end of the hierarchy. The Brazilian literature refers to these currencies as 'inconvertible currencies' because they cannot perform their money functions in the international context. A deeper discussion of this topic is found in Baltar (2013), Carneiro (2008), Conti (2011) and Prates (2002).

${ }^{7}$ In the case of Brazil, at the beginning of the liberalising reforms, the macroeconomic regime made use of a fixed or crawling-peg exchange rate, in combination with a more open-trade policy. The exchange rate was the price anchor and the use of high interest rates was designed to attract foreign capital for balance of payments purposes. After repeated financial crises, the crawling-peg exchange rate was abandoned and the flexible exchange rate and the Inflation Targeting Regime were introduced.
} 
where the sub-index t represents time.

According to Possas (1987), it is possible to distinguish two aspects of effective demand. The first aspect relates to the purchasing decision that can be from inside the economy (consumption, government expenditure and investment) or from abroad (exports). The second aspect concerns the performance of the effective demand regarding production, where part of the effective demand stays in the country in terms of GDP, i.e. national production, and part is lost for international production, i.e. imports. These two aspects of the effective demand are visualized by rearranging equation 6:

$$
C_{t}+I_{t}+G+X_{t}=Y_{t}+Q_{t}
$$

The effective demand materialises when the decisions for consumption, government expenditures and investment - purchases from inside the economy - and for exports - purchases from outside the economy - are taken, determining domestic production (Y) and imports (Q). The first aspect of the effective demand determining the economic activity is when domestic demand and external demand of domestic products are decided. These two demand decisions determine the second aspect, namely the effective demand determining the economic activity, i.e. domestic production, in terms of GDP, and imports. Hence, consumption, investment and government expenditures can be aggregated as domestic demand (D):

$$
\mathrm{C}_{\mathrm{t}}+\mathrm{I}_{\mathrm{t}}+\mathrm{G}_{\mathrm{t}}=\mathrm{D}_{\mathrm{t}}
$$

Domestic demand and exports determine the country's GDP and imports.

$$
D_{t}+X_{t}=Y_{t}+Q_{t}
$$

The growth rate of the effective demand equals the weighted average growth of domestic demand (d) and exports (x) on the left hand side and the weighted average of GDP growth (y) and imports (q) growth rate on the right hand side, as follows:

$$
(1-\theta) d_{t}+\theta x_{t}=(1-w) y_{t}+w q_{t}
$$


where $\theta$ is the proportion of the effective demand triggered by exports, i.e. $\theta=\frac{X}{D+X}$, and thus (1- $\left.\theta\right)$ corresponds to the proportion of the effective demand triggered by the domestic demand. Similarly, w is the proportion of the effective demand triggered by imports, i.e. $\mathrm{w}=\frac{Q}{Y+Q}$ and, thus, (1-w) is the proportion of the effective demand attended by domestic production. Rearranging equation 5, we have:

$$
\mathrm{y}_{\mathrm{t}}=[(1-\theta) /(1-\mathrm{w})] \mathrm{d}_{\mathrm{t}}+[\theta /(1-\mathrm{w})] \mathrm{x}_{\mathrm{t}}-[\mathrm{w} /(1-\mathrm{w})] \mathrm{q}_{\mathrm{t}}
$$

where $\mathrm{y}$ is economic growth, $\mathrm{d}$ is the growth rate of domestic demand, $\mathrm{x}$ is exports growth and $\mathrm{q}$ is imports growth.

Domestic demand (consumption, government expenditures and investment) is higher if GDP is greater. Consumption is traditionally considered as a function of GDP. Higher economic growth means more jobs and income for the population. The relationship between consumption and GDP emphasizes the role of investments determining GDP. The theory of the multiplier reveals how the level of GDP reacts to changes in investment, considering that consumption follows the GDP path, but by less than the full amount of the change in income (Matthews, 1959). The part of consumption formed by durable goods is purchased in instalments and access to credit is facilitated when the income of the population is higher. Hence, greater GDP means a more favourable situation that allows people to take debts. Investment, in turn, depends on the degree of productive capacity utilization. Greater GDP increases the use of this capacity, thereby inducing more investment (accelerator principle).

However, domestic demand is also influenced by the market interest rate that affects the cost to finance both consumption and investment. The capitalist evaluation of investments to increase the productive capacity also considers other possibilities of capital applications and accounts for high risk and low liquidity related to this type of capital application. Therefore, this investment should provide sufficiently high profitability to compensate for the high risk and low liquidity. The level of interest 
rate, then, indicates both the cost of financing and the capital application in relation to other existing alternatives. High market interest rates mean that only highly profitable investment could be undertaken, implying an inverse relationship between investment and interest rates: a lower level of interest rates reinforces the effects of GDP on domestic demand (consumption, government expenditures and investment) because lower interest rates imply lower financial costs and low profitability of other capital application vis-à-vis investments to expand the productive capacity.

A contribution of the model developed in this paper is the inclusion of the real exchange rate as another variable determining domestic demand. The reason is that the real exchange rate influences the impact of the GDP and market interest rates on domestic demand. In an open emerging economy with a macroeconomic policy that prioritizes low inflation, the performance of GDP and market interest rate depends on the international scenario in terms of trade and finance. The macroeconomic policy will enable higher GDP growth and lower market interest rate only if the international scenario positively affects the country's international reserves. Higher international reserves decrease the nominal exchange rate, pressing domestic inflation down. Thus, lower nominal exchange rate and domestic inflation, for a given international inflation, reduces the real exchange rate. ${ }^{8}$

A favourable international scenario for trade and finance, then, cheapens imported inputs, consumption goods and capital goods, thereby increasing domestic demand (consumption and investment). However, lower real exchange rate due to a favourable international scenario impacts negatively the price-competitiveness of domestic production. In this case, investment in tradable goods may be negatively affected (Lima and Porcile, 2012).

\footnotetext{
${ }^{8}$ Baltar (2015) proposes some equations for the behaviour of the real exchange rate that depends on international inflation, changes in the nominal exchange rate and domestic inflation. The nominal exchange rate is assumed to be a function of the balance of payments and domestic inflation is examined by separating the behaviour of tradable and non-tradable goods prices. International inflation is deduced from the evolution of the real exchange rate and inflation in Brazil, supplying information on changes in international prices that are important for this economy.
} 
However, investment may be stimulated by a favourable international scenario even if the national currency appreciates and reduces the price-competitiveness of domestic production. This would be the case of investment in the production of non-tradable goods and tradable goods in which the country has high comparative advantage. Thus, decreases in the real exchange rate will affect the composition of investment and not necessarily the volume of investment.

In this sense, the inclusion of the real exchange rate as a determinant of domestic demand is crucial to evaluating the specific effects of GDP and market interest rate on domestic demand. Changes in the real exchange rate indicate whether the international scenario favours or not the economic activity (GDP growth) and inflation; at the same time it designates the continuity of changes in GDP and the market interest rate that, in turn, affect domestic demand (consumption and investment). In other words, a favourable international scenario for trade and finance that positively affects the country's economic performance will increase the country's international reserves, appreciate the national currency, decrease domestic inflation, increase GDP growth, decrease the market interest rate and improve its public finance. Currency appreciation then synthesises these effects of the favourable international scenario for the country's economic performance, indicating the continuity of GDP growth, the reduction in the market interest rate, thereby reinforcing their effects on the domestic demand.

Under this positive scenario, families and firms expect that employment and income will increase, enabling them to seek debts. The same perception of low inflation and equilibrium in the balance of payments and public accounts stimulates banks to offer more credit. Therefore, higher credit increases domestic demand and GDP, signalling the continuity of higher economic activity. In this sense, the currency appreciation generated by the positive international scenario is interpreted by families, firms and banks as if the prosperity of the economy will continue. 
Conversely, an unfavourable international scenario will affect the balance of payments, thereby decreasing the country's international reserves, depreciating the national currency, increasing domestic inflation, decreasing GDP growth, raising the market interest rate and deteriorating the country's public finances. The currency devaluation would then synthesise the effects of the international situation, indicating the continuity of a poor performance for GDP and market interest rates, reinforcing the negative effects on domestic demand.

In short, the model considers that expectations on the continuity of the performance of the economy are influenced by inflation and the country's public account and balance of payments. The variable chosen to capture these expectations is, then, the evolution of the real exchange rate. So, the growth rate of domestic demand (d) is a function of GDP growth (y), the growth rate of the market interest rate (r) and the growth rate of the real exchange rate (rer):

$$
d_{t}=h_{1}+b_{1} y_{t}+b_{2} r_{t}+b_{3} r e r_{t}
$$

The growth rate of the real exchange rate is defined as $(1+$ rer $)=\left[\left(1+p_{i}\right)(1+e r)\right] /\left(1+p_{d}\right)$, where $\mathrm{p}_{\mathrm{i}}$ is international inflation, er is the growth rate of the nominal exchange rate, with the nominal exchange rate defined as domestic currency units per foreign currency units, and $\mathrm{p}_{\mathrm{d}}$ is domestic inflation. Government taxes are considered as given and their performance is included in the constant $h_{1} . b_{1}$ is expected to be positive due to the multiplier and accelerator effects. $b_{2}$ is expected to be negative due to the negative influence of interest rate on domestic demand. And the sign for the coefficient $b_{3}$ can be positive or negative, depending on the effects of the real exchange rate on domestic demand as discussed previously. Changes in the real exchange rate depend on changes in the nominal exchange rate and domestic and international inflations. The corresponding equations for each of these variables are reported in Baltar (2015). h represents a constant in all equations, changing the sub-index, and $b$ represents the coefficients of the model variables, also changing the sub-indexes. 
The growth rate of the market interest rate is considered as a function of the growth rate of the bank rate and the growth rate of the public debt. The bank rate is an exogenous variable set by the monetary authority and an increase in the bank rate raises the market interest rates. The model developed in this paper suggests to also include the public debt as an endogenous variable especially because its effect on the market interest rate is especially high for the case of a emerging economy. Usually, emerging countries do not possess large and developed domestic financial system. Besides that, the public debt tends to be high for the size of the domestic financial system and it tends to be a short-term public debt. ${ }^{9}$ Accordingly, to refinance the public debt, the interest rate tends to be high. If the interest rate for the public debt is high, private debt is attractive for the domestic financial market when its interest rate is also high. Consequently, the evolution of the public debt affects the market interest rate because the conditions to refinance the public debt depend on the evolution of this debt and impact the costs of credit for the private sector. So, an increase in the public debt tends to hamper the conditions to refinance this public debt and the interest rate increases. Consequently, private interest rate has to increase to make private loans attractive in the domestic financial market. Thus, increases in the public debt tend to raise the level of the interest rate of the domestic financial system.

The public debt in an emerging country has special characteristics which are not only due to fiscal unbalances. The fact that the public debt is high for the size of the domestic financial system and it is a short-term debt makes the refinancing of this debt more difficult, producing high interest rates with consequences for the evolution of the public debt. An increase in the public debt can materialise even when the government has primary surplus (tax revenues higher than the non-financial expenses of the government) and it does not need to take loans to finance the fiscal deficit. As a result, the refinancing of the public debt affects the level of the interest rate of the domestic financial system even

\footnotetext{
${ }^{9}$ For the case of Brazil, for example, the stock of the public debt in January 2006 was $46 \%$ of the GDP of the previous year. The average term of this debt was 28.76 months, i.e. 2.4 years; and $41 \%$ of this debt matures in 12 months (Lopreato, 2008). Because it is a short-term public debt, $46 \%$ of GDP is considered as very high.
} 
if tax revenues are higher than non-financial expenses of the government. Therefore, private sector assets will be attractive only if they promise to pay high interest rates.

So, the growth rate of the market interest rate is then a function of the growth rate of bank rate (br) and the growth rate of the public debt (pd):

$$
\mathrm{r}_{\mathrm{t}}=\mathrm{h}_{2}+\mathrm{b}_{4} \mathrm{br}_{\mathrm{t}}+\mathrm{b}_{5} \mathrm{pd}_{\mathrm{t}}
$$

$b_{4}$ and $b_{5}$ are then expected to be positive. Bank rate is considered an exogenous variable and the model determines endogenously the public debt growth.

The growth rate of the public debt shows the relationship between the total public deficit and the public debt. The total public deficit is the difference between tax collections and government financial and non-financial expenditures. The primary surplus is directly related with the GDP growth; therefore, the growth rate of GDP affects negatively the growth rate of the public debt. And the government financial expenditures are directly affected by inflation, bank rate and nominal exchange rate due to the public debt indexation. The public debt is indexed to inflation, bank rate or nominal exchange rate, depending on the economic circumstances. The inflation targeting regime and the high influence of the nominal exchange rate on domestic inflation makes the inclusion of domestic inflation in the equation of the public debt redundant. Hence, public debt growth depends on GDP growth rate, the growth rate of bank rate and the growth rate of the nominal exchange rate:

$$
\mathrm{pd}_{\mathrm{t}}=\mathrm{h}_{3}+\mathrm{b}_{6} \mathrm{yt}_{\mathrm{t}}+\mathrm{b}_{7} \mathrm{br}_{\mathrm{t}}+\mathrm{b}_{8} \mathrm{er}
$$

where $b_{6}$ is then expected to be negative and $b_{7}$ and $b_{8}$ are expected to be positive.

Baltar (2015) suggests that the nominal exchange rate is a function of lagged nominal exchange rate and changes in the balance of payments, showing that there is an inverse relationship between changes in the nominal exchange rate and the balance of payments (current and/or capital accounts). The balance of payments depends on the current and capital account, therefore considering the 
international situation in terms of trade and finance. Capital inflow increase international reserve, even if there is deficit in the current account, decreasing the nominal exchange rate, i.e. appreciating the national currency. Conversely, a reduction in international reserves increases the nominal exchange rate.

Exports and imports are modelled using standard equations. Accordingly, exports growth (x) depends on the world economic growth $(\mathrm{z})$ and the growth rate of the real exchange rate (rer). World economic growth positively affects exports because it increases the demand for national products. The real exchange rate also has a positive effect, since a higher real exchange rate means lower domestic price than the international price in domestic currency, thus making exports more competitive.

$$
\mathrm{x}_{\mathrm{t}}=\mathrm{h}_{4}+\mathrm{b}_{9} \mathrm{z}_{\mathrm{t}}+\mathrm{b}_{10} \mathrm{rer}_{\mathrm{t}}
$$

$b_{9}$ and $b_{10}$ are then expected to be positive.

And imports growth (q) depends on the domestic economic growth and changes in the real exchange rate. Higher GDP growth rate raises imports and an appreciation in the national currency makes imports cheaper, increasing them.

$$
\mathrm{q}_{\mathrm{t}}=\mathrm{h}_{5}+\mathrm{b}_{11} \mathrm{y}_{\mathrm{t}}+\mathrm{b}_{12} \mathrm{rer}_{\mathrm{t}}
$$

The sign of the coefficient $b_{11}$ is then expected to be positive and the sign of $b_{12}$ is expected to be negative.

In short, the standard theory considers that changes in the real exchange rate affect imports and exports, therefore impacting the country's GDP through the external trade. The data for Brazil after trade and financial liberalisation shows that the relationship between the real exchange rate and the Brazilian economic activity is more complex than what the standard theory implies. The model developed in this paper suggests that the world scenario, seen through the balance of payments, affects 
the real exchange rate and at the same time it influences consumption and investment, thereby affecting the country's GDP.

\section{Results for the Case of Brazil}

The model developed in this paper is estimated for the case of Brazil after the liberalising reforms from 1993 to 2014. The database is built with quarterly information from the Central Bank of Brazil (2016) and from IMF (2016). The model entails simultaneity, i.e. the growth rate of all GDP, domestic demand, market interest rate, public debt, nominal and real exchange rates, exports and imports are endogenous variables. Because of the simultaneity of the equations, the explanatory variables are jointly determined with the dependent variable and the regressors are not exogenous. Ordinary Least Squares (OLS) - a method for estimating the unknown parameters in a linear regression model generates consistent estimators only when the regressors are exogenous and there is no multicolinearity or simultaneity bias. However, the model's regressors are endogenous and OLS estimators would be inconsistent, blurring the impact of the explanatory variable on the dependent one, discarding the use of OLS.

Thus, the method used to estimate the parameters is the Generalized Method of Moments (GMM). The GMM allows consistent estimates of the parameters in the presence of endogenous variables amongst the explanatory variables. GMM is a robust estimator because it does not require information of the exact distribution of the disturbances. GMM estimation is based upon the assumption that the disturbances in the equations are uncorrelated with a set of instrumental variables. Hence, it is important to find instruments that are not correlated with the error term such as the predetermined variables (Wooldridge, 2003), i.e. lagged endogenous variables, which can be treated as 'safe' instrumental variables. The Vector Error Correction also accounts for endogeneity; however, as we will 
see later, the variables do not adhere to the unit-root principle. Therefore, the most appropriate econometric methodology is the GMM.

We follow Hendry and Richard (1983) to build the econometric analysis and evaluate the quality of the estimations. The first step is to check whether the data is coherent. Tests for stationarity are undertaken, such as the Augmented Dick-Fuller (ADF) and the Durbin Watson (DW) tests, for this purpose. The true value of the parameters based on the sample estimate is tested with the use of the Wald test, which indicates whether the fitted model describes well the relevant data. The inclusion of lagged dependent and independent variables is also considered in the estimation; this is to verify whether these lagged variables have an influence on current values. Hendry and Richard (op. cit.) suggest including four lags for the dependent variable in the case of quarterly data and eliminating the non-significant ones. The Root Mean Square Error and the R-squared statistics are also considered to measure the goodness of fit of the statistical model. The instruments used for the estimations are also lagged endogenous variables and the number of lags are decided through the 'partial $\mathrm{R}^{2 \prime}$ (Shea, 1997) and the 'J-statistic' (Hansen, 1982).

The ADF test was performed on all variables to verify whether they are stationary and present the same order of integration. The test does not indicate unit root, suggesting the variables may be stationary and may have the same order of integration. To reassure stationarity, after all estimations, the DW test is performed on each variable to verify whether the combination of the variables is stationary. ${ }^{10}$

Table 2 shows the result for all estimations. The coefficients of each variable were significant at 1\%. The goodness of fit was checked through the R-squared and the Root Mean Square Error (MSE) statistics. Following Hendry and Richard (1983) approach, lagged dependent and independent variables

\footnotetext{
${ }^{10}$ The results for the ADF test are available from the authors upon request.
} 
were included in the estimations, improving the goodness of fit of the model as indicated by the Rsquared and Root MSE results. Each estimated equation is commented subsequently.

Table 2: Estimations of the Model Equations (Method GMM)

\begin{tabular}{|c|c|c|c|c|c|}
\hline Variable & $\mathrm{d}_{\mathrm{t}}$ (eq. 12) & $\mathrm{r}_{\mathrm{t}}$ (eq. 13) & $\mathrm{pd}_{\mathrm{t}}$ (eq. 14) & $\mathrm{x}_{\mathrm{t}}($ eq. 15) & $\mathrm{q}_{\mathrm{t}}($ eq. 16) \\
\hline Constant & $-0.99 * *$ & $-5.21 *$ & $4.44 *$ & $1.22 *$ & $0.75^{*}$ \\
\hline $\mathrm{d}_{\mathrm{t}-1}$ & $0.04 *$ & & & & \\
\hline$d_{t-2}$ & $0.11 *$ & & & & \\
\hline $\mathrm{y}_{\mathrm{t}}$ & $1.34 *$ & & $-1.21 *$ & & $2.31 *$ \\
\hline $\mathrm{y}_{\mathrm{t}-1}$ & & & $-0.17 *$ & & $0.98 *$ \\
\hline $\mathrm{y}_{\mathrm{t}-2}$ & $1.74 *$ & & & & \\
\hline $\mathrm{Z}_{\mathrm{t}}$ & & & & $1.78 *$ & \\
\hline $\mathrm{Z}_{\mathrm{t}-2}$ & & & & $1.94 *$ & \\
\hline $\mathrm{r}_{\mathrm{t}}$ & $-0.11 *$ & & & & \\
\hline $\mathrm{r}_{\mathrm{t}-2}$ & & $0.49 *$ & & & \\
\hline $\mathrm{br}_{\mathrm{t}}$ & & $0.38 *$ & $0.51 *$ & & \\
\hline $\mathrm{br}_{\mathrm{t}-1}$ & & $0.40 *$ & & & \\
\hline $\mathrm{pd}_{\mathrm{t}}$ & & $0.45^{*}$ & & & \\
\hline $\mathrm{pd}_{\mathrm{t}-1}$ & & $0.14 *$ & $-0.15^{*}$ & & \\
\hline $\mathrm{q}_{\mathrm{t}-1}$ & & & & & $0.07 *$ \\
\hline $\mathrm{q}_{\mathrm{t}-2}$ & & & & & $0.13 *$ \\
\hline rer $_{t}$ & $-1.42 *$ & & & $0.05^{*}$ & $-0.15^{*}$ \\
\hline $\operatorname{rer}_{\mathrm{t}-1}$ & & & & $0.16^{*}$ & $-0.30 *$ \\
\hline $\mathrm{er}_{\mathrm{t}}$ & & & $0.42 *$ & & \\
\hline $\mathrm{er}_{\mathrm{t}-2}$ & & & $0.19 *$ & & \\
\hline \multicolumn{6}{|c|}{$*$ significant at $1 \%, * *$ significant at $5 \%$} \\
\hline Instruments & $\begin{array}{c}\mathrm{y}_{\mathrm{t}-1}, \mathrm{r}_{\mathrm{t}-2,}, \mathrm{r}_{\mathrm{t}-3} \\
\operatorname{rer}_{\mathrm{t}-2,2}, \mathrm{rer}_{\mathrm{t}-3}, \mathrm{rer}\end{array}$ & $\begin{array}{l}b_{\mathrm{t}-2-2}, \mathrm{br}_{\mathrm{t}-3}, \mathrm{br}_{\mathrm{t}-4} \\
\mathrm{pd}_{\mathrm{t}-2,}, \mathrm{pd}_{\mathrm{t}-3,}, \mathrm{pd}_{\mathrm{t}-4}\end{array}$ & $\begin{array}{c}\mathrm{y}_{\mathrm{t}-3,3}, \mathrm{y}_{\mathrm{t}-4,}, \mathrm{y}_{\mathrm{t}-5}, \mathrm{br}_{\mathrm{t}-1} \\
\mathrm{br}_{\mathrm{t}-2,}, \mathrm{br}_{\mathrm{t}-3}, \mathrm{er}_{\mathrm{t}-2,}, \mathrm{er}_{\mathrm{t}-3}\end{array}$ & $\begin{array}{l}\mathrm{z}_{\mathrm{t}-2}, \mathrm{Z}_{\mathrm{t}-3}, \mathrm{z}_{\mathrm{t}-4} \\
\mathrm{rer}_{\mathrm{t}-3}, \mathrm{re} \mathrm{re}_{\mathrm{t}-4}\end{array}$ & 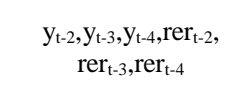 \\
\hline Observations & 88 & 88 & 88 & 88 & 88 \\
\hline R-squared & 0.42 & 0.63 & 0.59 & 0.41 & 0.65 \\
\hline Root MSE & 29.3 & 21.1 & 15.5 & 15.0 & 7.5 \\
\hline Wald stat & $4855.2(\mathrm{prob}=0)$ & $0.0003(\mathrm{prob}=0)$ & $4328.4(\mathrm{prob}=0)$ & $2221.9(\mathrm{prob}=0)$ & $24325.8($ prob $=0)$ \\
\hline Durbin Watson d-stat & 1.96 & 1.70 & 2.10 & 2.15 & 2.40 \\
\hline J-test & $1.9563(\mathrm{p}=0.7438)$ & $2.0717(\mathrm{p}=0.5577)$ & $2.2824(\mathrm{p}=0.8088)$ & $2.3928(\mathrm{p}=0.7925)$ & $1.7122(\mathrm{p}=0.7885)$ \\
\hline Shea's (1997) Partial R-sq & $\begin{array}{c}12 \% \text { for } y_{t}, 15 \% \text { for } y_{t-} \\
2,13 \% \text { for } \mathrm{r}_{\mathrm{t}}, 42 \% \text { for } \\
\operatorname{rer}_{\mathrm{t}-1}\end{array}$ & $\begin{array}{c}16 \% \text { for } \mathrm{br}_{\mathrm{t}}, 17 \% \text { for } \\
\mathrm{br}_{\mathrm{t}-1,1} 24 \% \text { for } \mathrm{pd}_{\mathrm{t}} \\
14 \% \text { for } \mathrm{pd}_{\mathrm{t}-1} \\
\end{array}$ & $\begin{array}{l}77 \% \text { for } \mathrm{y}_{\mathrm{t}}, 50 \% \text { for } \\
\mathrm{y}_{\mathrm{t}-1}, 24 \% \text { for } \mathrm{br}_{\mathrm{t}}, 33 \% \\
\text { for } \mathrm{e}_{\mathrm{t}}, 29 \% \text { for } \mathrm{er}_{\mathrm{t}-2} \\
\end{array}$ & $\begin{array}{c}33 \% \text { for } \mathrm{z}_{\mathrm{t}}, 46 \% \text { for } \\
\mathrm{z}_{\mathrm{t}-2}, \\
37 \% \text { for rer }, 47 \% \\
\text { for rer } \mathrm{r}_{\mathrm{t}-1} \\
\end{array}$ & $\begin{array}{c}56 \% \text { for } \mathrm{y}_{\mathrm{t}}, 68 \% \text { for } \\
\mathrm{y}_{\mathrm{t}-1}, \\
10 \% \text { for rer } \\
\operatorname{rer}_{\mathrm{t}-1}, 11 \% \text { for } \\
\end{array}$ \\
\hline
\end{tabular}


The instruments used for each estimation are indicated in the Table. The Shea's partial Rsquared test shows that the instruments are relevant to explain all endogenous regressors. This result is reinforced by the J-statistic tests, that shows that the over-identifying restrictions are satisfied, so the instruments can be used as exogenous variables as a group. Therefore, the instruments are not correlated with the error, which is an important condition for the GMM estimation. The Wald test indicates the value of the parameters based on the sample estimate is true and the Durbin Watson tests are close to two, suggesting that the combination of the variables is stationary.

The estimation of the domestic demand equation indicates its evolution as directly related to GDP rate and inversely related to variations in the interest rate and real exchange rate. The variable used for the market interest rate is the referential rate swaps, pre-fixed DI 360 days, average of the period. The literature on Brazil considers that this is the most appropriate interest rate to represent the evolution of taxes of the domestic financial market (Prates and Farhi, 2009). This variable is available only after 1999. So, the extrapolation technique is used to generate the data series from 1993 to 1998 , using the available data to predict the missing information.

GDP growth rate affects domestic demand through its effect on consumption and investment. This coefficient is significant and positive, the same verified for lagged GDP growth. Accordingly, higher GDP means more jobs and income for the population, increasing consumption. Besides that, greater GDP increases the use of the productive capacity, consequently inducing more investment. The inclusion of lagged GDP growth rate is important because it is not only the GDP growth in the present time that affects domestic demand growth, but the decisions for consumption and investment are also influenced by the economic performance in the previous period. Therefore, if greater economic growth is followed by higher growth rate in the previous period, the effect of the economic performance on consumption and investment will be greater. 
The market interest rate affects domestic demand through its effect on the costs to finance consumption and investment and it also signals alternative capital application, especially in financial assets. The coefficient of this variable is significant, showing the importance of the market interest rate for the determination of economic growth.

Last but not least, the rate of change of the real exchange rate has a negative effect on domestic demand growth. The negative coefficient of this variable means that an appreciation in the national currency has a positive effect on consumption and investment. The interpretation of this result is that currency appreciation contributes to higher GDP growth rate because it indicates a favourable international scenario, the last seen through an improvement in the country's balance of payments (surplus in the current account and/or capital inflow), that increases the country's international reserves. The nominal exchange rate decreases with the improvement in the balance of payments, pressing domestic inflation down (Baltar, 2015). The interest rate decreases with inflation, favouring credit. But, the decrease in inflation and the strengthening of the balance of payments reinforce the effect of a decrease in the interest rate on credit, therefore increasing consumption and investment. Lower inflation and equilibrium in the balance of payments help to consolidate continued economic growth. Banks would then offer more credit and families and firms would make more debts, increasing consumption and investment.

The coefficient of the rate of change of the real exchange rate is significant and very high, being even greater than the coefficient for the market interest rate. So, a favourable economic scenario (higher international reserves and lower inflation), seen through the real exchange rate, may stimulate consumption and investment, even if it negatively affects the country external trade.

In this sense, the results confirm that the effect of the real exchange rate on the Brazilian economic activity after trade and financial liberalisation is more complex than what the standard theory implies. The Swan diagram, for example, shows two types of relationship between domestic demand 
and real exchange rate: one that determines product and employment, and another that determines trade balance. Different combinations of domestic demand and real exchange rate generate different relationships between product/employment and trade balance. For a given domestic demand, higher real exchange rate implies better trade balance and therefore greater product and employment. And for a given real exchange rate, greater domestic demand stimulates imports, decreasing the trade balance, therefore reducing the effect of great domestic demand on product and employment. The diagram shows that only one combination of domestic demand and real exchange rate generates full employment product with trade equilibrium. The Swan diagram is not able to show properly this complex effect of the real exchange rate on the level of economic activity. The diagram does not consider that changes in the real exchange rate may also affect domestic demand, apart from the traditional effect on the external balance. The diagram suggests that an appreciation in the national currency affects negatively the country's external trade, decreasing its economic activity. To compensate for this lower economic activity, an increase in autonomous domestic demand is necessary. In this sense, the diagram ignores that the circumstances that appreciate the national currency may have favourable induced effects on consumption and investment. The estimation result suggests that these induced effects were crucial in the recent experience of the Brazilian economy.

The second estimated equation is the market interest rate that affects the cost to finance consumption and investment. The bank rate is set by the monetary authority and has a direct impact on the market interest rate. This effect is also seen through previous values for bank rate growth, as suggested by the significant coefficients for the lagged bank rate growth. In this case, market interest rate increases due to increases in the bank rate as well as the behaviour of the bank rate in the past, i.e. if the bank rate was increasing previously, this increase will positively influence the market interest rate in the present. 
The estimation for the market interest rate equation shows that, for a given bank rate, the market interest rate tends to be higher if public debt is high, confirming our theoretical model. Hence, in circumstances of increases in the bank rate, the impact on the market interest rate will also depend on the public debt growth. Conversely, in circumstances of decreases in the bank rate, reductions in the market interest rate also depends on changes in the public debt. Both bank rate and public debt variations should then negatively influence effective demand through market interest rate and domestic demand. The inclusion of the bank rate, as a mechanism to control inflation, and public debt, crucial for the interest rate of the domestic financial market, allows verifying the negative effect of increases in both variables on the financing conditions of the Brazilian economy.

The next estimated equation is the public debt growth. The coefficient for economic growth is negative as expected, indicating that when GDP growth increases, the government earning from taxes raises. The coefficients for changes in the bank rate and in the nominal exchange rate are positive, signalling that an increase in both variables enhances public debt.

The estimation of the exports growth equation shows that the relationship between exports and world economic growth is significant. The real exchange rate also affects exports significantly, confirming the standard theory. Accordingly, higher world economic growth as well as the national currency depreciation influence positively the Brazilian exports.

Exports growth has a direct impact on the effective demand, increasing GDP growth rate. Besides that, exports are also important for the balance of payments. If exports are higher than imports, the country has surplus in trade. Depending on the amount of this surplus, the current account may be in surplus. This result is verified in Brazil for several years after 2003, when commodity prices had a sharp increase, augmenting Brazilian exports. With surplus in the current account, combined with capital inflow, the country increased its international reserves. Consequently, the country's vulnerability 
was reduced and the Brazilian economy was able to experience faster and continued economic growth after a long period of low and unstable economic activity.

What seems to be peculiar in the Brazilian case after trade and financial openness is the relationship between the real exchange rate and the GDP growth rate. Economic growth tends to be higher in periods of appreciated national currency and lower in periods of depreciated national currency. This relationship between real exchange rate and GDP growth rate may reinforce the relationship between imports growth and product growth. This is because when GDP exposes high growth rates and national currency appreciates, imports are very high.

The estimation of the Brazilian imports growth equation shows that the influence of the Brazilian GDP growth rate on this country's imports is very high. This result is expected in a country that depends on imports and decides to open its trade to the rest of the world. Besides this, the national currency appreciation also stimulates imports growth considerably and this currency appreciation occurs in Brazil when GDP growth is greater. The combination of higher economic growth and appreciated currency results in very high imports, explaining the very high growth rate of imports when Brazilian GDP growth is greater.

For an economy to be able to sustain this higher economic growth and the consequent high imports, exports should be greater, despite the currency appreciation. Higher exports then require greater world economic growth and that this economic growth stimulates increases in demand and price for the products Brazil has comparative advantage for its exports.

The estimation results show that the income elasticity of demand for exports is much lower than the income elasticity of demand for imports. This means that the Brazilian GDP growth rate, consistent with the equilibrium in trade, is lower than the world economic growth. Capital movements that occurred in the relevant period under examination contributed to improve the performance of the 
Brazilian economy and this performance was reinforced by the international boom of commodities that highly increased the Brazilian exports.

After the liberalising reforms there are two periods of higher economic growth: from 1993 to 1997 and from 2004 to 2008, whose dynamics confirm the economic structure revealed by the model and estimations of this study. Higher exports growth materialised in the second period, and it allowed more consistent economic growth with trade surplus. In the first period, GDP growth rate tended to decline and there was trade deficit. After 2009, when the Great Recession affected Brazil, the changes of the world scenario and of the country are no more able to sustain the previous growth rates.

In short, the estimations of this study confirm its model propositions, explaining why the Brazilian economic growth has been slower and more unstable after the liberalising reforms. Higher economic growth depends on exports through its direct effects on the effective demand and through its indirect effects on the balance of payments that set a better macroeconomic scenario. Higher international reserves decrease the nominal exchange rate, reducing inflation. Consequently, demand and supply of credit increase, despite the high level of interest rates, raising consumption and investment.

However, the currency appreciation affects negatively the country's external trade, stimulating imports and dampening exports. In this case, induced investment would occur in the production of nontradable goods or in the production of tradable products where the country already has comparative advantage. Hence, the short-term dynamics of production and price may not be the most convenient for the long-run growth trend, because it exposes the country to a high dependence on the international situation, leaving the country vulnerable to the world scenario. The Great Recession, and the difficulties to sustain higher and continued economic growth rates, illustrate this dependence. 


\section{Summary and Conclusions}

This paper suggests a model of growth for an emerging country. This model was estimated for the Brazilian case after the liberalising reforms and the results confirm the relationships suggested by the model. One important result is that the real exchange rate affects in different directions the domestic demand and the country's external trade, suggesting that the influence of the real exchange rate is more complex than what the standard theory proposes, at least for the case of Brazil and in the period under investigation.

In favourable circumstances for the balance of payments, the national currency appreciates and the external trade is negatively affected due to imports stimulus and the negative influence on exports. However, consumption and investment are positively affected because under healthy balance of payments circumstances, domestic inflation decreases, GDP growth increases and the currency appreciation signals the continuity of higher GDP growth and lower inflation, thereby stimulating the demand and supply of credit. In circumstances of worse balance of payments, the national currency depreciates, positively affecting exports and negatively affecting imports; and domestic demand is negatively affected because worse balance of payments is followed by lower GDP growth and higher inflation. In this case, the currency depreciation signals to families, firms and banks the continuity of lower economic growth and higher inflation, therefore harming the demand and supply of credit.

The estimation of the model shows the direct influence of exports on the effective demand. However, exports have an even greater indirect effect, creating the conditions for higher domestic demand through the balance of payments. The possibility of higher exports and surplus in the current account is very important for an emerging country such as Brazil because of the structural deficit in the case of the current account of the balance of payments that is related to services. This deficit in services is mainly a consequence of the payments of interest of the external debt plus remittances of profits and dividends. The remittances of profits and dividends tend to increase when the national currency 
appreciates. Another item of the deficit in services, which also increases when the national currency appreciates, is tourism. So, the equilibrium in the balance of payments is dependent on capital inflows, unless exports are higher than imports, and consequently there is surplus in trade and/or in the current account. Besides that, financial openness made the Brazilian financing highly dependent on capital inflows (international loans, foreign application in the domestic financial market and foreign direct investment). So, capital inflows are important for the equilibrium in the balance of payments and for the financing of the economy. Continued capital inflow presupposes a good performance of exports.

The balance of payments is crucial to create the favourable circumstances for domestic demand because it enables lower inflation and appreciates the national currency. The model suggests that a favourable international scenario for exports growth and capital inflow helps to decrease the bank rate and the public debt growth, favouring the domestic demand through a reduction in the interest rate of the domestic financial system. The robustness in the inflation reduction and in the equilibrium of the balance of payments, with increases in international reserves and capital inflow higher than the deficit in current account, induce expectations of continued higher GDP growth, employment and income. Therefore, demand and supply of credit may increase, despite the high level of interest rate of the domestic financial system.

Continued economic growth depends on favourable international conditions for trade and finance. The high effect of the international scenario on the country's performance reveals that the real exchange rate hinders the national development of tradable goods production, and higher GDP rate becomes more dependent on the world economic growth. The latter became greater after 2003 with an increased participation of Asia, particularly China, benefiting the domestic GDP rate of countries that produce commodity goods. But the national currency was appreciated, increasing imports and concentrating the incentives for investment in the production of non-tradable or in tradable goods that the country already has comparative advantage. Therefore, the Brazilian vulnerability to the world 
scenario in terms of trade and finance did not weaken. When the world scenario changes, such as after the Great Recession, the Brazilian vulnerability is exposed.

To conclude, the new development strategy implemented in Brazil with the liberalising reforms made it possible to lower inflation but GDP growth became highly dependent on international trade and finance. The results of the model show that when Brazil has higher economic growth, it is associated with an appreciated exchange rate. This is because the appreciation of the national currency helps to lower inflation and together with the accumulation of reserves, a favourable environment is created, thereby stimulating consumption and investment. Under these conditions, the financial system modifies the composition of financial assets, lowering public debt assets and increasing private loans to firms and especially to families. Hence, GDP growth rate is favoured even if part of the effective demand goes abroad through imports.

Thus, when the national currency appreciates, domestic demand (consumption and investment) is high, but investment is not necessarily induced to develop exports and to compete with imports. Consequently, investment may only reinforce the existing productive structure without contributing to decrease the existing productive delay. Therefore, increases in imports are high and part of the effective demand is transferred abroad. The current account of the balance of payments is then negatively affected. Exports are still dependent on the international scenario without developing the productive capacity that produce exports of new products with higher demand in the international market. Even if part of the effective demand is transferred abroad, GDP growth rate can be high in the short-run. However, the country's performance becomes dependent on a favourable international scenario and the conditions for a better performance under an unfavourable international scenario are not created. Consequently, even if the country experiences short periods of relatively higher economic growth, this growth rate is unstable and the long-run growth trend is weak. 


\section{References}

Araujo, R.A. and Lima, G.T. (2007) A Structural Economic Dynamics Approach to Balance-ofPayments-Constrained Growth. Cambridge Journal of Economics.

Araujo, R.A, Teixeira, J.R. and Soares, C. (2015) "Export-led growth vs growth-led exports: what matters for the Brazilian growth experience after trade liberalization?" Review of Keynesian Economics, vol. 3 (1), pp. 108-128.

Baltar, C.T. (2013) Economic Growth and Inflation in an Open Developing Economy: The Case of Brazil. PhD Thesis, Darwin College, Cambridge.

Baltar, C.T. (2015) "Inflation and Economic Growth in na Open Developing Country: the case of Brazil”. Cambridge Journal of Economics, vol. 39 (5), pp. 1263-1280.

Belluzzo, L. G. and Almeida, J. G. de (2002) Depois da Queda: a economia brasileira da crise da dívida aos impasses do Real. Rio de Janeiro: Civilização Brasileira.

Bresser-Pereira, L.C. (2009) "The Tendency to Overvaluation of the Exchange Rate". In: BresserPereira, L.C. (ed.) Globalization and Competition, Cambridge University Press.

Bresser-Pereira, L.C. (2011) A Taxa de cambio no Centro da Teoria do Desenvolvimento. Escola de Economia de São Paulo.

Britto, G. (2008) Economic Growth in Brazil from a Kaldorian Standpoint. PhD Thesis, Darwin College, Cambridge.

Carneiro, R. (2002) Desenvolvimento em Crise: a economia brasileira no último quarto do século XX. São Paulo: UNESP Editor, IE-Unicamp.

Carneiro, R. (2008) Impasses do Desenvolvimento Brasileiro: a questão produtiva. Discussion Paper, IE/UNICAMP, n. 153.

Carvalho, V.R.S., Lima, G.T. and Santos, A.T.L. (2005) A restrição externa como fator limitante do crescimento econômico brasileiro: um teste empírico. Econontro Nacional de Economia, Anpec.

Carvalho, V.R. and Lima, G.T. (2009) "Estrutura produtiva, restrição externa e crescimento econômico: a experiência brasileira". Economia e Sociedade (UNICAMP), v. 18, pp. 31-60.

Central Bank of Brazil (2011) Database, time series information for economy and finance, URL: http://www.bcb.gov.br/?TIMESERIESEN.

Cimoli, M. and Porcile, G. (2010) "Global Growth and International Cooperation: a structuralist perspective”. Cambridge Journal of Economics, 35, p.383-400.

Conti, B. (2011) Políticas Cambial e Monetária: Os Dilemas Enfrentados por Países Emissores de Moedas Periféricas. PhD Thesis. Campinas: IE/Unicamp.

Davidson, P. (2001) "The Principle of Effective Demand: Another View". Journal of Post Keynesian Economics, vol. 23 (3), pp. 391-409.

Dixon, R., and A.P. Thirlwall (1975) A Model of Regional Growth Rate Differences on Kaldorian lines. Oxford Economic Papers. 
Dixon, R., and A.P. Thirlwall (1979) A model of esport-led growth with a balance of payments constraint. In Bowers, J. (ed) Inflation, Development and Integration: essays in honour of A.J. Brown, 173-193. Leeds University Press.

Dopfer, K., Foster, J. and Potts, J. (2004) "Micro-meso-macro". Journal of Evolutionary Economics, Springer, vol. 14(3), pages 263-279.

Dosi, G.; Soete, L. (1988) “Technological Change and International Trade”. In: DOSI, Giovanni et al. (Eds.) Technical Change and Economic Theory. London: Pinter, 1988.

Ferreira, P.C. and Rossi, J.L. (2003) "New Evidence from Brazil on Trade Liberalization and Productivity Growth”. International Economic Review, vol. 44 (4), pp. 1383-1405.

Hansen, L. (1982) "Large Sample Properties of Generalized Method of Moments Estimators". Econometrica 50(3), p. 1029-1054.

Hanusch, H. (1999) The Legacy of Joseph A. Schumpeter, Edward Elgar Publishing, number 1182, April.

Hendry, D.F. and Richard, J.F. (1983) "The Econometric Analysis of Economic Time Series". International Statistical Review, vol. 51, n. 2, pp. 111-148.

IEDI (2007) Empresa Nacional: A Atratividade da Empresa Brasileira. Analise IEDI. URL: www.iedi.org.br

IEDI (2012) A Dupla Assimetria Cambial e os Efeitos Sobre a Indústria Brasileira. Carta IEDI no 516. URL: $\underline{\text { ww.iedi.org.br }}$

IMF (2010) World Economic Outlook, April.

Jayme Jr, F.G. (2003) "Balance of Payments Constrained Economic Growth in Brazil". Brazilian Journal of Political Economy, 23 (1), pp. 62-84.

Kaldor, N. (1967) Strategic Factors in Economic Development, New York: Ithaca.

Lall, S. (2003) "Technology and Industrial Development in an Era of Globalization”. In Chang, H.J. (Org.) Rethinking Development Economics. London: Anthem Press.

Lima, G.T. and Porcile, G. (2012) Economic Growth and Income Distribution with Heterogeneous Preferences on the Real Exchange Rate. Mimeo.

Lisboa, M.B., Menezes Filho, N.A. and Schor, A. (2010) "The Effects of Trade Liberalization on Productivity Growth in Brazil: competition or technology?". Revista Brasileira de Economia, v. 64 (3), pp. 277-289.

Lopez, J. and Cruz, A. (2000) Thirlwall's Law "and beyond": the Latin American Experience. Journal of Post Keynesian Economists, vol. 22, n.3.

Lopreato, F.L.C. (2008) Problemas de Gestao da Divida Publica Brasileira. Discussion Paper IE/UNICAMP, No. 139.

Malerba, F. (2002) "Sectoral systems of innovation and production," Research Policy, Elsevier, vol. 31(2), pages 247-264, February.

Matthews, R.C.O (1959) The Trade Cycle. Welwyn, Herts.: J Nisbet, Cambridge (Eng.): University Press. 
McCombie, J.S.L. and Thirlwall, A.P. (1994) Economic Growth and the Balance-of-Payments Constraint. London: Macmillan Press LTD.

Mesquita Moreira, M. and Najberg, S. (2000) "Trade Liberalisation in Brazil: creating or exporting jobs?". The Journal of Development Studies, vol. 36 (3), pp. 78-99.

Moreno-Brid, J. C. (1998-9) On Capital Flows and the Balance-of-Payments Constraint Growth Model. Journal of Post Keynesian Economics, 21(2), 283-297.

Moreno-Brid, J. C. (2003) Capital Flows, Interest Payments and the Balance-of-Payments Constrained Growth Model: a theoretical and empirical analysis. Metroeconomica, 54(2-3_, 346-365.

Nassif, A. (2006) Há evidências de Desindustrialização no Brasil? BNDES Discussion Paper, $\mathrm{n}^{\circ}$ 108, Rio de Janeiro.

Nassif, A., Feijo, C. And Araujo, E. (2011) The trend of the real exchange rate overvaluation in open emerging economies: the case of Brazil. Discussing Papers UFF/ECONOMIA.

Pacheco-López, P. and Thrilwall, A.P. (2005) Trade Liberalisation, the Income Elasticity of Demand for Imports and Growth in Latin America. University of Kent.

Palma, G. (2005) Four Sources of "De-industrialisation" and a New Concept of the "Dutch Disease". In Ocampo, J.A. (Ed.) Beyond Reform: Structuural Dynamics and Macroeconomic Vulnerability. Stanford: Stanford University Press, pp. 71-116.

Possas. M.L. (1987) Dinâmica da Economia Capitalista: uma abordagem teórica. 1 ed. São Paulo, SP: Brasiliense.

Prates, D. (2002) Crises Financeiras nos Países "Emergentes”: uma Interpretação Heterodoxa. PhD Thesis. Campinas: IE/Unicamp.

Prates, D. And Farhi, M. (2009) A crise financeira internacional, o grau de investimento e a taxa de cambio real. Discussion Paper, IE/UNICAMP, n.164.

Rodrik, D. (2004) Rethinking growth strategies. WIDER Annual Lecture 8, United Nations World Institute for Development Economics Research, Helsinki.

Saviotti, P. and Pyka, A. (2004) "Economic development by the creation of new sectors". Journal of Evolutionary Economics, Springer, vol. 14(1), pages 1-35.

Setterfield, M. (2010) “Endogenous Growth: A Kaldorian Approach”. In: Harcourt, G.C. and Kriesler (Ed.) Handbook of Post Keynesian Economics, Oxford, Oxford University Press.

Thirlwall, A.P. (1979) The Balance of Payments Constraint as an Explanation of International Growth Rate Differences. Banca Nazionalee del Lavoro Quarterly Review, 128, pp. 45-53.

Thirlwall, A.P. (2011) Balance of Payments Constrained Growth Models: History and Overview. KDPE 111, University of Kent, School of Economics Discussion Papers.

Thirlwall, A.P. and Hussain, M.N. (1982) The Balance of Payments Constraint, Capital Flows and Growth Rate Differences between Developing Countries. Oxford Economic Papers, 34(3), 498510.

Wooldridge, J.M. (2003) Introductory Econometrics: a modern approach. $2^{\text {nd }}$ edition, New York: Thomson Learning. 